tively privileged international, or, in the case of the United States, out-of-state students.

Recently, Cambridge University released a report sounding the alarm about the adverse effects of Brexit on Cambridge, and on British higher education generally. I doubt that the average working-class family in the industrial midlands-slammed by decades of economic upheaval and decline in the brave "new economy"-would sing a sad song for Cambridge or university dons more generally. Neither would those ${ }^{5} 5^{-20}$ percent of people living in poverty in Cambridge. That is understandable. For the new economy appears to be very much like the old economy, in terms of who reaps the prime benefits and who does the principal tough labor.

Partly, the backlash has also intersected and animated the political deconstruction of the social democratic compact and the welfare state.

Class inequities between labor and capital are increasing internationally, straining our social democratic compacts and institutions. University academics and executives must certainly redouble their efforts and discover new ways to work more effectively against the xenophobia-and racism, misogyny, and homophobia-that defines so much of right-wing populism. But we would also do well to learn a lesson from the rise of populism, by committing ourselves to bridge the social class divide that plagues the academy and society, dividing us into nations of a relatively few haves and too many have-nots. We need to find ways to realize more fully our social responsibility to democratize the societies in which we are situated. That should mean rebalancing and enhancing the global and the local, to enhance the opportunities and lives of the social class "others," domestically and internationally, who continue to be relatively invisible and relegated to educational oblivion by our policies, practices, and belief systems in academe.

DOI: http://dx.doi/org/Io.6oI7/ihe.20I7.89.9756

\section{Trump and the Coming Rev- olution in Higher Education Internationalization}

\section{Philip G. Altbach and Hans de Wit}

Philip G. Altbach is research professor and founding director, and Hans de Wit is professor and director, Center for International Higher Education, Boston College, US. E-mail: altbach@bc.edu; dewitj@bc.edu.

T $n$ recent months, we have seen the beginning of a sea1 change in the patterns of higher education internationalization that have been entrenched and rapidly expanding during the past half-century. The most recent minitsunami is the implementation of several restrictions on citizens of seven predominantly Muslim countries from entering the United States, and the havoc that has created. Brexit, inward-looking nationalist governments in Poland and Hungary, and the rise of the populist right in Europe are all parts of what might be called the "new world order" of higher education internationalization. While some observers feel that current patterns will continue, we disagree. We are not arguing that mobility will end or that the academic community itself is abandoning internationalization as a goal, and certainly not that the commercial interests that have recently entered the internationalization "marketplace" will stop. But we do think that we are at the beginning of a fundamental period of change.

One must keep in mind that higher education internationalization is a set of concepts and a series of operational programs. The concepts include a recognition of the positive elements of globalization and an understanding that it is a permanent element of the world economy; a commitment to global understanding; respect for diverse cultures; and an open society welcoming cooperation between different political, cultural, and economic partners. Internationalization is also often seen as part of a nation's "soft power" influence. The operational side of internationalization has in recent years become big business-many billions of dollars, euros, and other currencies are spent on internationalization programs and earned by universities, private companies, and a vast array of providers, insurance companies, recruiters, and others. International students contributed more than $\$ 32.8$ billion to the US economy. And UK universities currently earn around one-eighth of their income from tuition fees paid by international students. These students also contribute around $£ 7$ billion a year to the economy.

Although the more idealistic aspects of international- 
ization have been modified in recent years by commercialization and profit-seeking, basic goals are, and will remain, fairly stable. Overall, the academic community will remain committed to these positive goals. The operational end is likely to be seriously upended, with considerable implications for internationally mobile students, academics seeking overseas mobility or collaboration, and for universities and governments that have come to rely on income from mobility in all of its aspects. The future of more than 200 international branch campuses, mainly sponsored by European and US universities, and located worldwide-many in Muslim-majority countries — might be in jeopardy.

\section{At the same time, we will see many uni- versities and their faculty and students in the United States and in Europe re- sist these trends and take initiatives to promote international solidarity, coop- eration, and exchanges.}

\section{External Realities}

Global political realities are changing by the hour, as shown by the immigration restrictions of the Trump administration. Further implementation of "extreme vetting" can be expected. Changing policies by the British government relating to defining international students as immigrants also create instability. Changes in policies and in opinions about the role of student and academic mobility can be expected in the coming period in some European countries. In the year of the 35th anniversary of the European flagship program ERASMUS, the future of this program and of others in research cooperation and higher education capacity building may be threatened or will see severe budget cuts, as a result of growing anti-European feelings among rightwing parties and their supporters. In the West, the trend toward "border closing," or at least tightening restrictions, may well get worse. It is unclear whether countries affected by Western discriminatory policies will retaliate, creating a kind of "trade war" for higher education internationalization.

There are also counterexamples. Canada has made it clear that it will keep its doors open and expand programs for international mobility, keeping available a path to citizenship for graduates from other countries. Others, including China and India, may strengthen their policies aimed at attracting international students and staff. The existing trend toward increasing mobility within the Asian, Latin American, and African regions, and between these regions, will speed up.

The rhetoric and policies of Trump, May, and others do not even need to be fully implemented. Occurrences of hostility and discriminatory practices, incidences of harassment at border crossings, difficulties in obtaining visas, and numerous other problems, real or perceived, will affect how people think about mobility and internationalization. The genie is out of the bottle, and cannot easily be put back.

Internationalization has been perceived as a Western concept, benefiting mainly the developed world. With the West shutting itself out, the next revolution of higher education internationalization might well take place among developing and emerging economies.

\section{Likely Consequences}

While it is impossible to predict the exact consequences of the trends outlined above, several results seem likely:

- There will be significant changes in patterns of student mobility, affecting mostly the market share of the United Kingdom and the United States, which is already declining.

- Global perceptions of the United States and the United Kingdom, and of other European countries that follow their lead toward intolerance and xenophobia, will suffer, weakening the dominance of these countries in global academic rankings, research collaboration, and other aspects of higher education prestige.

- Public higher education institutions in the United States and the United Kingdom will likely suffer the biggest impact, with a further decrease of public funding, combined with lower numbers of fee-paying international students.

- Smaller universities and colleges, already facing demographic challenges, and often dependent on international student enrollments, will risk closure.

- Branch campuses and other forms of cross-border education from the United States and the United Kingdom will stall—while universities from other regions, including India and China, will fill their places. Current host countries of Western branch campuses, in the Middle East and elsewhere, may become less eager to support them.

- Scholarship schemes like Fulbright in the United States and ERASMUS in Europe will face severe budget cuts, which will contribute to reductions in mobility of students and faculty.

- Internationalization, already perceived to be elitist, will likely only be afforded by prestigious universities. 
At the same time, we will see many universities and their faculty and students in the United States and in Europe resist these trends and take initiatives to promote international solidarity, cooperation, and exchanges. Global citizenship, a concept denied by Trump and May, will become a key factor in the fight of universities for autonomy and academic freedom. The reactions of academic leaders, faculty, and students in US universities and colleges to the restrictions imposed by the Trump administration, are a clear manifestation of their opposition. These reactions are not driven by a fear of losing revenue, but by their attachment to the core values of higher education.

DOI: http://dx.doi/org/Io.6oI7/ihe.20I7.89.9758

\section{Academic Staff Mobility in the Age of Trump and Brexit?}

\section{LiUdvika Leisyte and Anna-Lena Rose}

Liudvika Leisyte is professor of higher education, and Anna-Lena Rose is research and teaching assistant and doctoral student at the Center for Higher Education, Technical University of Dortmund, Germany. E-mail: liudvika.leisyte@tu-dortmund.de; anna-lena.rose@tu-dortmund.de.

\begin{abstract}
A cademic mobility and the attractiveness of higher education systems are increasingly associated with excellence, the creation of dynamic, international networks, enhanced scientific performance, improved knowledge and technology transfer, and ultimately improved economic and social welfare. The success of higher education institutions, measured in terms of high-quality teaching and research output and the attraction of large research grants, is strongly influenced by the academic staff they employ. In times of growing international competition, the ability to attract talented academic staff is the key ingredient of success for universities and economies worldwide. Yet, current political developments, characterized by increasing populism, nationalist tendencies, and strong anti-immigration discourses might lead to significant shifts in traditional patterns of international academic staff mobility.
\end{abstract}

Traditional Mobility Patterns

Austria and the United Kingdom (where 25 percent of aca- demic staff are foreign nationals), Denmark, Ireland, the Netherlands, and Norway (30 percent), Luxembourg and Switzerland (more than 50 percent) are the European countries that have attracted most foreign academic talent in Europe up to now. The 2016 Science and Engineering Indicators show that in the United States, more than half of the postdoctoral workforce is foreign born. Existing patterns of academic mobility do, however, tend to reinforce inequalities between academic centers such as those mentioned above and academic peripheries (to speak in Altbach's terms), which are usually located in smaller, geographically remote, and economically weaker countries, and constitute less attractive destinations for international academic staff. Traditional losers of the brain-gain and brain-drain dynamics of international academic staff mobility include Central and Eastern European (CEE), South European, Latin American, and some Asian countries, as well as many developing countries across the world.

Our recent study of patterns of academic staff mobility in CEE countries-Estonia, the Czech Republic, and Lithuania (traditionally closed systems characterized by transition economies, distinctive cultures and histories, and protectionism of their national languages) has revealed that these countries struggle both to retain and to attract academic talent, resulting in predominantly outbound mobil-

Estonia stands out as a best-practice
example in implementing concrete poli-
cies and imposing clear targets at both
national and institutional levels for
opening recruitment and attracting for-
eign academic talent.

ity flows. Key barriers to attracting talented academic staff from abroad include comparatively low salary levels, a lack of transparency in recruitment and promotion procedures, high degrees of nepotism and academic inbreeding, as well as a lack of foreign language competencies among older generations of local academic staff. In the Baltic States, especially in Latvia, further barriers are created by local language requirements for foreign academic staff. We observed that academics moving to CEE countries seem to be motivated by factors that differ from those moving to other countries in the world. Instead of career progression, access to knowledge and equipment, autonomy and academic freedom, and lower teaching loads and more time for research, 